\title{
Environmental Issues in City Logistics: The Case of Low Emission Zones in Europe
}

\author{
Gilles Paché ${ }^{1} \&$ Christian Morel $^{2}$ \\ ${ }^{1}$ CRET-LOG, Aix-Marseille University, Aix-en-Provence, France \\ ${ }^{2}$ Jonction Consulting, Aix-en-Provence, France \\ Correspondence: Professor Gilles Paché, CRET-LOG, Aix-Marseille University, 413 Avenue Gaston Berger, \\ 13625 Aix-en-Provence Cedex, France. E-mail: gilles.pache@univ-amu.fr
}

\author{
Received: December 3, 2020 Accepted: February 2, $2021 \quad$ Online Published: February 22, 2021 \\ doi:10.5539/jms.v11n1p88 URL: https://doi.org/10.5539/jms.v11n1p88
}

\begin{abstract}
The energy transition can be defined as all the transformations of the system of production, distribution and consumption of energy carried out in a territory in order to make it more ecological. The aim is to reduce the environmental impact of an energy system. Inseparable from sustainable development, the energy transition contributes to the fight against global warming, through the implementation of changes based on innovative technologies, but also and above all on new political orientations. The paper focuses in particular on city logistics in Europe as an illustration of energy transition, showing that strategic interactions between city logistics stakeholders are at the heart of new practices, particularly in the implementation of low emission zones (LEZs). A case study was conducted with a large French metropolitan area, which is at the forefront of sustainable city logistics. This case study is based on an analysis of official documents written as part of the implementation of the LEZ. Using a conceptual framework drawn from the SCP paradigm, which is at the origin of the industrial organization's stream, the results indicate that the success of environmental city logistics strategies depends effectively on interactions between several public and private stakeholders, and not only on virtuous managerial practices from companies.
\end{abstract}

Keywords: city logistics, energy transition, Europe, low emission zones (LEZs), SCP paradigm, sustainability

\section{Introduction}

The energy transition is a theme that attracts the growing attention of European decision-makers (de la Esperanza Mata Pérez et al., 2019). It is not simply about building wind turbines and solar panels; it is linked to economic and managerial issues as diverse as access to energy, the adequacy between production and consumption, or the fair price and cost of energy production. The environmental issues are now widely known. Among the activities identified as contributing to the achievement of the objectives set, particularly in terms of reducing greenhouse gas emissions, the weight of road freight transport remains significant, despite the many efforts and reductions observed over the past 20 years through successful sustainable supply chain strategies (Andrés \& Padilla, 2018). Indeed, it is not so simple and mechanical to reduce this contribution, as logistics remain an essential support function for economic activities, and more particularly for exchange and trading activities. The integration of logistical activities as a strategic skill of the company requires adequate investment choices, both in terms of equipment and human resources.

The objective of this investigation is to better understand the system of constraints underlying the energy transition in a particular context: the extreme downstream of supply chains responsible for delivering products in cities on the basis of highly capillary logistics schemes. These involve both local authorities and companies, which interact to meet the environmental requirements of a more sustainable city logistics (Somuyiwa, 2010; Patier \& Routhier, 2020). The conceptual framework used to highlight the importance of the political dimension as a key element in the functioning of supply chains is the SCP paradigm. The SCP paradigm, which emerged in the 1960s from the founding work on industrial organization, specifies that the regulatory environment strongly influences the strategic behavior of companies, beyond market structures alone. While the SCP paradigm is rarely used in current management research, it has an intact heuristic power applicable to the governance of supply chains, e.g., the way in which the supply chain members mediate between the different product flow monitoring constraints (Richey Jr. et al., 2010). 
This paper is structured as follows. After having first recalled the fundamentals of the SCP paradigm, we will then discuss the organization of sustainable city logistics with reference to a system of environmental constraints that combines an economic and a regulatory perspective by taking the case of low emission zones (LEZs). They radically change the conditions of access to urban space by companies, both for convenience stores and online buyers, and consequently their strategic behavior. The case of the Lyon metropolitan area, which has set up a LEZ for 2020, will be used to show how strategic interactions are essential between stakeholders in defining a LEZ that respects local specificities. More generally, sustainable city logistics emphasizes that environmental challenges are essential, as they are more generally for logistics management, which focus "not only on the satisfaction of private economic interests of business entities, but also at ensuring of resource conservation and environmental safety" (Koblianska, 2018, p. 46). The paper will end with a conclusion on the research avenues opened by this exploratory reflection.

\section{Conceptual Framework}

Originally driven by Mason's (1939) work in the United States in the late 1930s, the SCP paradigm (which stands for structure, conduct [or strategic behavior] and performance) is one of the structuralist foundations of contemporary industrial analysis. It is still used today as a relevant analytical framework to identify relationships between the structure of a market, the strategic behavior of companies in that market and the resulting economic and societal performance:

- The structure is based on a set of variables that are relatively stable over time and influence the behavior of sellers and/or buyers. The presence of imperfect competition in the sense of Chamberlin (1933) and Robinson (1933/1969) depends essentially on the degree of concentration of supply, demand, product differentiation, available technology and barriers to market entry.

- Strategic behavior is similar to the way in which the above-mentioned buyers and sellers behave with each other in a competitive sphere defined by the home industry. Companies choose their own policies to differentiate themselves from their competitors, both in terms of production (investments, relocations, contracts, etc.), as well as in terms of prices or $\mathrm{R} \& \mathrm{D}$.

- Finally, performance is measured by analyzing the commercial and financial results of companies in the industry with reference to different ratios used to assess different levels of profitability and efficiency (level of retail price, product quality, resource allocation, efficiency of logistics organization, etc.).

\subsection{SCP Paradigm}

In his book Industrial organization, Bain (1959/1987) truly developed the SCP paradigm to give it a more sophisticated form and allow it to constitute a robust starting point for the analysis of markets and industries, not only in economics, but also in business management. The multiplication of sector studies within the Harvard Business School has led to the accumulation of important material for acquiring a general knowledge of how markets actually work. From the synthesis of these studies, Bain (1959/1987) hopes to identify general economic laws leading to a new market and price system theory. However, researchers in management, especially Porter (1980), will understand the interest of the SCP paradigm for analyzing the competitive strategies of companies. Porter's (1980) seminal work on competitive forces is based on the paradigm in a more or less explicit way. The Porterian reasoning, which has its roots in industrial organization, is based on the principle that the performance of an industry, with potential benefits for consumers, but also for the Society as a whole, is determined by the strategic behavior of companies within their industry, which in turn results from the structure of the market.

The SCP paradigm states that efficiency and profitability are determined by the strategic behaviors (drivers) of companies. Such a vision is attractive insofar as it is based on a simple and mechanistic reasoning: the market environment has a direct and short-term impact on the market structure, the market structure then having a direct influence on the company's strategic behavior, which in turn affects its performance on the market. In this case, the feedback effects are such that market performance can influence strategic behavior and structure, or strategic behavior can influence market structure. In brief, from a renewed perspective of the SCP paradigm, companies are no longer passively constrained by their environment but are in an active position to change it. Furthermore, external factors will be taken into account to understand competitive dynamics: political interventions from national, regional or local regulatory authorities (Scherer \& Ross, 1990).

Figure 1, adapted from the reference book of Scherer and Ross (1990), highlights the importance of government intervention in various ways, both in terms of structure, strategic behavior and performance. Government intervention can take the form of regulations (e.g., legal entry barriers), taxes and subsidies, investment incentives or anti-trust policies. From a broader perspective, we can see here the exercise of a, sometimes 
underestimated, "political game" which will have a more or less strong and lasting impact on competitive conditions, maintaining the relevance of the SCP paradigm (Uzunidis, 2016). Of course, this political game can take place on a national, even supranational, scale, but with the recent emergence of territorial governance, particularly in Europe (Schmitt \& Van Well, 2015), such interventionism is also sometimes in the hands of local authorities, whose decisions will have important effects on the strategic behavior of companies.

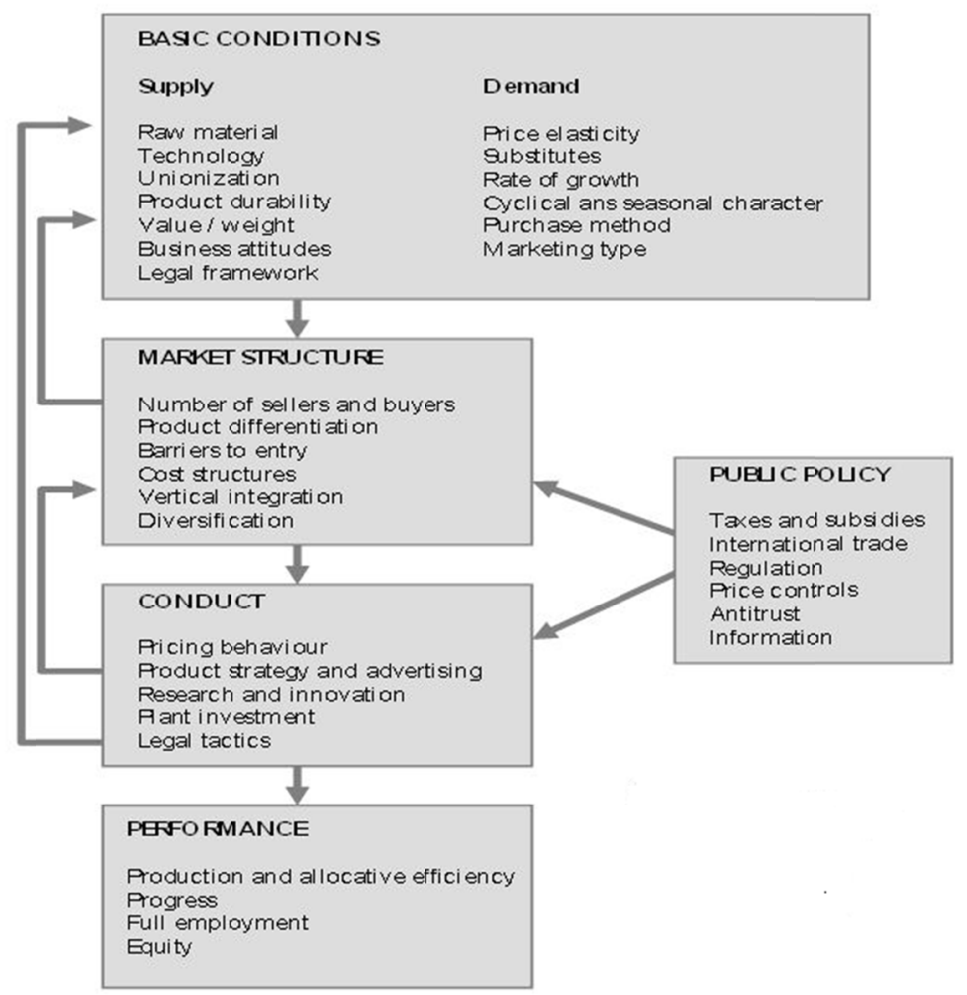

Figure 1. The extended SCP paradigm

Source: Adapted from Scherer and Ross, 1990.

At the end of the 1970s, the main developments of a "new industrial organization" deepened the study of product differentiation and monopolistic competition, as well as the formalization of oligopoly situations. The Nobel Prize Tirole (1988) is one of its most emblematic authors. In contrast to the SCP paradigm, the new industrial organization focuses on behaviors (corporate strategies), and no longer on structures, which are considered endogenous. It abandons econometric cross-sectional studies on a set of sectors in favor of monographic econometric studies. The new industrial organization was made possible in particular by developments in game theory and, more broadly, by the deepening of microeconomic theory in a situation of imperfect competition. Among the constituent elements of imperfect competition, the game played by political authorities plays a significant role, particularly in the deployment of sustainable logistics. As underlined by Sedaghatnia et al. (2013), the action of policy makers is today essential in the development of sustainable neighborhoods.

This interventionism, or public policy according to the SCP paradigm, is directly related to the rapid changes in city logistics, characterized by the explosion of direct deliveries to consumers. In France, e-commerce accounted for nearly $9 \%$ of retail trade in 2019 , two-thirds of which were delivered to homes and one-third to alternative locations (pick-up points, filling stations, train stations, etc.). The major impact is the increase in road traffic, which translates into an increase in pollution in the city, especially in mega-cities. Regarding Paris for example, freight transport accounts for 10 to $20 \%$ of traffic, but it is responsible for a quarter of $\mathrm{CO}_{2}$ emissions, a third of $\mathrm{NO}_{\mathrm{x}}$ (nitrogen oxide) emissions and half of the PM10 particles associated with urban traffic (Dablanc et al., 2017; Host et al., 2020). Under these conditions, a laissez-faire approach on the part of local authorities cannot be considered, at the risk of lastingly altering the residents' quality of life. 


\subsection{Public Policy in the Context of Sustainable City Logistics}

According to Savelsbergh and Van Woensel (2016, p. 79), "city logistics is about finding efficient and effective ways to transport goods in urban areas while taking into account the negative effects on congestion, safety, and environment. The distinguishing characteristic of city logistics is the explicit recognition that transporting goods in urban areas has a negative (as well as a positive) impact on the lives of people living in these urban areas". The case of city logistics is particularly representative of the interventionism of local authorities, in the search of more ecological and social systems (da Silva Batalhao et al., 2018). The simple reference to the multiplication of experiments in Europe for a green and smart city based on the coordinated control of flows is enough to be convinced of this. The main aim of these cities is to reconcile technological innovation with the economic, social and ecological challenges of tomorrow. Three cities are particularly advanced:

- Barcelona (Spain). The city has equipped itself with sensors to manage lighting, green spaces and traffic lights. In addition to intelligent waste collection to optimize travel, mobility and traffic are at the heart of the reflections. Barcelona has been asked by the World Bank to develop a smart city standard that can be applied in other European countries.

- London (United Kingdom). With the continuous increase in its population, the city has been developing a sustainable approach for several years. In order to involve its inhabitants, it has set up the "Talk London" platform, which brings together all the useful information needed to live, work and travel in London. In terms of mobility, London was a pioneer in introducing an urban road toll in 2003.

- Oslo (Norway). Action is focused on intelligent lighting: 10000 street lamps have been equipped with sensors to adjust brightness according to the seasons and lighting requirements (the aim is to reduce electricity consumption by $70 \%$ ). The city has also done away with the use of private cars in urban areas by implementing an ambitious mobility policy based on a comprehensive public transport offer.

Step by step, with the adoption of a "smart" perspective, a growing number of municipalities are seeking to regulate the delivery of products in the city by implementing binding regulations that force companies to adapt their strategic behavior, particularly in terms of logistics. While the autonomous development of "winning logistics strategies" was the managerial credo of the 1990s and 2000s, a major breakthrough was introduced in the 1990s, at the same time as supply chains saw the reappearance of local trade in urban areas: companies' logistics strategies must promote pooling processes, including with competitors, to avoid blockages in flows that cause negative environmental externalities. Logistics pooling, imposed by local authorities, consists of grouping the orders of different customers in the same city, or even in the same district, within the same transport unit in order to massify the flow and optimize the various aspects related to the delivery activity. From the point of view of the inhabitants, logistics pooling means a better vehicle fill rate (VFR), more efficient rounds, and consequently fewer trucks in the city. In short, as the SCP paradigm emphasizes, political decisions, such as the obligation to comply with compulsory logistics pooling or loosely, to give specific rights to operators managing pooled infrastructures (Borsenberger, 2018), exert constant pressure on the behaviors that need to be identified.

Europe has been subject to an increasing number of energy transition directives for several years (Thieffry, 2016; Gauthier \& Lowitzsch, 2019). After a long period of little or no political involvement at this level, many countries, including France (Andriosopoulos \& Silvestre, 2017), are seeking to make up for lost time, particularly through the definition of low-carbon strategies and the development of clean mobility (see Box 1 and Table 1). The underlying idea is that it is important to bring national policies into line with the various European directives, even if some subjects, such as the application of the "polluter pays" principle (Grillo \& Laperrouze, 2013), are still under study because of the lack of a societal consensus. Public policies, through the articulation of the different spatial planning schemes and their application to the different decision-making levels, now integrate the energy transition into a vision integrating a strategic dimension, an economic dimension and the different resources to be implemented to enable the vision to be achieved. However, the question of sustainable city logistics refers to specificities in terms of delivery, one of the best known of which is the last mile management.

Box 1. Launching of an innovative program

By adopting a national low-carbon strategy, introduced with the "Energy Transition Act for Green Growth", France is committed to reducing its greenhouse gas emissions by $75 \%$ in 2050 compared to 1990 . In this context, economic stakeholders (logistics service providers, wholesalers, manufacturers, large and small retailers) will also need support to adapt to ecological and energy imperatives, while maintaining their economic competitiveness. The InTerLUD program supports 50 communities of different sizes - 15 large metropolises, 25 medium-sized conurbation communities and 10 small conurbation communities - and capitalises on the lessons learned to 
disseminate them at the national level. It aims to create or strengthen the necessary spaces for dialogue between public and private stakeholders in the same area as well as at the national level, to support the transition towards more sustainable city logistics.

Source: Adapted from a Cerema document, October 2020.

Table 1. Implementation of European directives on the energy transition at the French level

\begin{tabular}{|c|c|c|}
\hline European directives & Objective & Adaptation in France \\
\hline $\begin{array}{l}\text { Ambient air quality and } \\
\text { cleaner air for Europe }\end{array}$ & Improving air quality, especially in cities & Promulgation of Decree No. $2010-1250$ \\
\hline National emission limits & $\begin{array}{l}\text { Definition of air pollutant emission limits by } \\
2025-2030\end{array}$ & National Low Carbon Strategy \\
\hline $\begin{array}{l}\text { Promotion of the use of energy from } \\
\text { renewable sources }\end{array}$ & $\begin{array}{l}\text { Use of at least } 10 \% \text { renewable energy in } 2020 \text { for } \\
\text { the transport of products and people }\end{array}$ & $\begin{array}{l}\text { Multi-annual energy programming and } \\
\text { development scheme for clean mobility }\end{array}$ \\
\hline Eurovignette & $\begin{array}{l}\text { Polluter pays principle by internalizing the external } \\
\text { costs caused by heavy trucks using road } \\
\text { infrastructure }\end{array}$ & No national adaptation \\
\hline Alternative fuels infrastructure & Deployment of infrastructure for alternative fuels & $\begin{array}{l}\text { National Framework for Action for the } \\
\text { Development of Alternative Fuels }\end{array}$ \\
\hline Euro standards & $\begin{array}{l}\text { Definition of maximum pollutant emission limits } \\
\text { for vehicles }\end{array}$ & Adoption of Euro standards \\
\hline
\end{tabular}

Source: The authors.

By its very nature, the regulations resulting from European directives impose constraints on the use of public space. In the majority of cases, these constraints are expressed by restrictions, even bans on travelling or stopping for delivery vehicles (Nuzzolo et al., 2016; Lopez, 2018). However, it should not be forgotten that the regulation must also take into account the specific constraints of the city, while being readable and understandable both by companies, which will have to comply with it and adapt their responses to it, and by the multiple stakeholders of the city logistics system, first and foremost professional customers and end customers to whom the products are addressed. These are both prescribers (opening hours determine delivery times, commercial practices determine the frequency and size of shipments) and users of urban space, with duality sometimes creating dissonance phenomena. Thus, the inhabitants appreciate the presence of convenience stores, but they reject the drawbacks related to their supply. For their part, companies will not always have an interest in developing environmental organizations by sharing their experiences with competitors, even though a rapid reduction in carbon emissions requires strategic inter-firm cooperation. The task of the political decision-maker is therefore difficult to reconcile divergent interests, sometimes even for the same economic agent, using efficient sustainability indicators (da Silva Batalhao et al., 2019).

Technically, the policy maker, acting as "town planner" (Olaitan, 2019), will seek to combine parameters such as vehicle size or delivery times. It must be noted that vehicle tonnage remains at the center of decision-making processes, including in response to road congestion problems in highly constrained topographical cities (Pulawska \& Starowicz, 2014). The length, width or ground surface of the vehicles are also considered relevant, as well as the delivery time and/or duration (Lagorio et al., 2016; Akyol \& De Koster, 2018). However, it should be noted that other more recent parameters are beginning to be mentioned by some cities, such as the type of motorization, the maximization of the filling rate, or the pooling of deliveries between competing companies (Morana et al., 2014; Montoya-Torres et al., 2016). All these parameters have in common that they explicitly raise the question of the exercise of control in terms of human and technical resources, with control aids designed to make the devices effective (time disc, road tax disk, automatic recognition of registration plates). But one of the most significant and promising advances is undoubtedly the sectorization of urban space, as evidenced by the development of low emission zones.

\section{Low Emission Zones: An Application}

Low emission zones (LEZs) are territories in which access is prohibited, if necessary, over specific time periods, for different categories of vehicles that do not meet certain emission standards, and which therefore have a harmful impact on the health of the territory's inhabitants (Tögel \& Spicka, 2014). More or less explicitly, the objective here is to fight two major problems: congestion, a source of energy waste, and environmental pollution. This system has already proved its worth in several countries such as Germany, Portugal and the United Kingdom in environmental matters (Ellison et al., 2013; Jiang et al., 2017; Santos et al., 2019; Ku et al., 2020), since its 
introduction in 1996 in three Swedish cities (see Box 2). While these areas are now deployed in a growing number of European cities, national legislation aims to see them quickly spread to other cities, particularly those whose air pollutant concentration thresholds are regularly exceeded.

\section{Box 2. Sweden at the forefront of LEZ development}

Sweden is the first country to implement LEZs, as a measure to reduce pollution from vehicles and to stimulate retrofitting diesel trucks and buses with exhaust emission control devices. Since 1992, Swedish cities could legally ban heavy duty vehicles from entering "environmentally sensitive areas". In 1996, Sweden started with LEZs in Stockholm, Gothenburg and Malmö. Retrofitted vehicles carried official vehicle inspection stickers required for LEZ entry. In 2006, the individual regulations of environmental zones in different municipalities in Sweden are replaced by a national regulation and incorporated in the existing traffic regulation. The new regulation aims to harmonize the requirements for different municipalities, for the benefit of transportation companies working on a national scale. Since January 2020, municipalities are able to introduce three different kinds of LEZs. It will be up to cities themselves to decide whether and where LEZs should be applied. In 2020, Sweden has LEZs in Stockholm, Gothenburg, Malmö, Lund, Helsingborg, Umeå, Uppsala and Mölndalen.

Source: Retrieved from https://making-cities-safer.com/low-emission-zones-white-paper

A LEZ aims to reduce polluting emissions in the city by forcing the replacement of older vehicles, and not to restrict traffic or fluidify traffic; other public actions make it possible to work on these subjects, for example the creation of pedestrian zones, which are not those of the LEZs, in the service of improving air quality. The founding principle of the LEZ is that the older a vehicle is, the more it pollutes. By forcing the renewal of the vehicle fleet, a gain in pollutant emissions is mechanically achieved. This correlation between age and pollution level is due to the increasingly strict obligations on automotive manufacturers with regard to the maximum quantities of pollutants that a vehicle sold in Europe is allowed to emit. These levels, which are regularly revised downwards, mean that a current vehicle complying with the Euro 6 standard pollutes much less than an equivalent vehicle sold a few years ago, and it actively contributes to the development of an "ecological mobility" (Hulkkonen et al., 2020).

\subsection{A Major Step Forward for Sustainable City Logistics}

For many countries, poor air quality in cities is the cause of premature deaths (for example, nearly 50000 in France and nearly 700000 in the European Union each year). The increase in road traffic is the main reason why the limit values for $\mathrm{NO}_{2}$ (nitrogen dioxide) and PM10 particle concentrations are exceeded. In order to reduce the dramatic urban pollution, several European countries have implemented LEZs; in April 2020, there were 247 LEZs in 13 European countries, on very concentrated geographic areas (see Figure 2). LEZs can be limited to a few square kilometers, such as Ilsfeld in Germany $\left(2 \mathrm{~km}^{2}\right)$, or to an entire urban area, such as Greater London in the United Kingdom $\left(1500 \mathrm{~km}^{2}\right)$. The most LEZ-inclined countries are Germany and Italy: they account for $85 \%$ of the LEZs recorded in Europe. On the other hand, France can be considered one of the poor students since the European Commission initiated two pre-litigation procedures in 2017 for non-compliance with the limit values for $\mathrm{NO}_{2}$ and PM10 particles. Most often, the vehicles targeted by these areas are heavy trucks, buses and coaches. However, each country or even each zone may notify certain specificities. Thus, light vehicles of individuals and companies are concerned in Germany, and Italy has chosen to include motorized two-wheelers.

Since the creation of the first LEZs in the 2000s, several studies have assessed their environmental performance. The first results are particularly encouraging since cities that have introduced LEZs have seen a reduction in pollutant emissions from road traffic, with reductions in air concentrations of PM10 particles sometimes exceeding $10 \%$ (Cyrys et al., 2014). For its part, the French Agency for the Environment and Energy Management (ADEME) underlines that while existing LEZs have a limited effect on $\mathrm{NO}_{\mathrm{x}}$ and/or $\mathrm{NO}_{2}$ concentrations, they have a significant effect on PM2.5 particle concentrations and black carbon concentrations, a component of fine particles (Pouponneau et al., 2019). In the specific case of London, a decrease in $\mathrm{NO}_{2}$ concentrations of about $20 \%$ was recorded at measuring stations close to road traffic within the LEZ between April 2017 and April 2019. Another interesting example is the city of Leipzig, in Germany. The implementation of the LEZ has led to an accelerated modernization of the vehicle fleet, and in the first four years of operation, toxic concentrations of soot and ultrafine particles were reduced by $47 \%$ and $56 \%$ respectively. This reduction is broadly similar to the reduction in the LEZ of Berlin. 


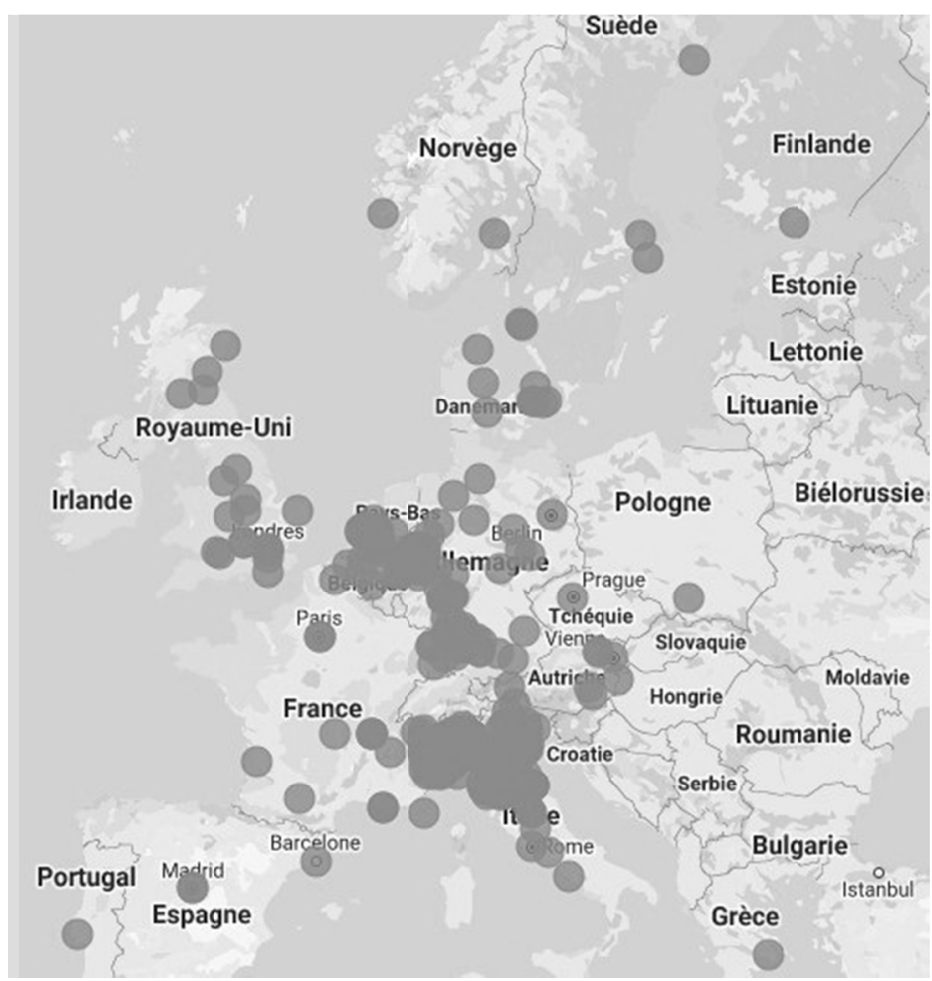

Figure 2. Concentration of geographic areas with LEZs in Europe (2020)

Source: www.urbanaccessregulations.eu (Accessed November 30, 2020)

The definition of a LEZ regulatory project involves a combination of several elements leading to different scenarios, which have a direct impact on the management of product traffic in the city. The choice of vehicles concerned in terms of traffic, with the substitution of dirty vehicles by green vehicles (Wolff, 2014), the scope of application of a LEZ as well as the level of possible restrictions are the three main parameters to be set in an interventionist way of thinking. Then comes the triple question of the derogations to be granted and its corollary, its temporality, as well as its progressive implementation (step by step implementation and evolution schedule):

- Regulated object. The heavy trucks concerned are mainly held by professionals in the road transport of goods whose ability to adapt to change (adaptability) is the highest, compared to other socio-professional categories.

- Perimeter. The wider the scope of application, the higher the environmental efficiency for populations. However, some relatively attractive areas concern many external users, in addition to the vehicles present.

- Level of restriction. Regulation contributes to technological breakthroughs and the development of new engines (electric, hydrogen, gas). As such, it is a powerful lever for cleaning up the fleet in favor of less polluting vehicles.

- Progressiveness. The challenges related to the implementation schedule are twofold: (1) it makes it possible to introduce progressive regulations in line with the natural evolution of the fleet; (2) it gives visibility to the various road users, who will be able to plan their vehicle replacement better and anticipate the cost involved.

- Derogations. Whether temporary or permanent, the derogations allow certain categories of vehicles to be excluded from the rule for various reasons, including the low mileage they cover compared to their purchase cost.

- Temporality. Temporality is to be compared to the derogatory regime because it makes it possible to avoid the LEZ being applicable in all places, and at all times. It allows categories of users the freedom to travel at certain times of the day or on certain days of the week.

In brief, current measures in sustainable city logistics, of which LEZs are a key component, refer to two types of decisions. The first decisions are of a regulatory nature. They set obligations (standards), or conversely provide for prohibitions. In Europe, regulatory decisions are the most widely used tools in the field of air quality and, more generally, environmental protection. In particular, they make it possible to prevent the most immediate and serious 
damage, and they are of immediate scope. The control of their application and, if necessary, a system of sanctions, are the corollary of their effectiveness. The second decisions are of a budgetary nature. They aim to assess and understand air pollution phenomena better and to improve the energy and environmental performance of goods (aid for the purchase of clean vehicles) or activities (encouraging the choice of virtuous delivery systems). Budgetary decisions are the result of a political will based on the assumption of responsibility by the community for certain investments or expenditures.

Reducing greenhouse gas emissions, improving urban air quality and facilitating the energy transition to improve a "green city branding" policy (Busch \& Anderberg, 2015): this is ultimately the triple challenge of the environmental changes underway under the LEZ framework. This can only be done in the massive presence of clean vehicles made available to companies. For the time being, a significant effort has been made for light commercial vehicles. Thus, for the year 2017, the average $\mathrm{CO}_{2}$ emissions of new personal-use vehicles sold in France amounted to $111 \mathrm{~g} \mathrm{CO}_{2} / \mathrm{km}$, whereas they were still $122 \mathrm{~g} \mathrm{CO}_{2} / \mathrm{km}$ in the European Union in 2014. The decrease in average $\mathrm{CO}_{2}$ emissions from new vehicles is largely due to technological developments in vehicles: they emit less carbon dioxide and are therefore no longer impacted by the environmental penalty. A similar effort remains to be made for light commercial vehicles, at the heart of urban deliveries, to support the renewal of city center trade (Levy et al., 2018).

However, the implementation of LEZs faces two main limitations (Martayan et al., 2020). The first limitation is related to the "locus of control". Considering the place given to autonomy in our societies, restrictions on movement can be perceived as an infringement on individual freedoms. In order to counteract this dispossession and to reintroduce a locus of control in individuals, it is useful to develop prior consultation and citizen participation mechanisms. The second limitation is related to the "feeling of fairness". It follows from the distribution of the efforts and benefits induced by the implementation of a LEZ. If some stakeholders consider that they have to make a significant effort while others are exempted (vehicles of foreign carriers, for example), then the acceptability of the new organization decreases. Similarly, if the benefits are perceived as primarily benefiting categories considered to be favored (e.g., inner-city residents), the social acceptability of the new organization is diminished. These two limitations require a particularly convincing communication policy. In order to understand the stakes of the LEZs implementation better, a survey was conducted at the LEZ of Lyon, which is the most advanced project in France with Paris. Box 3 specifies the methodology used to collect the information.

\section{Box 3. Methodology}

The investigation on the Lyon's LEZ is based on an analysis of secondary data collected by the authors over a three-year period, at four different levels: (1) official documentation on LEZ regulations published by several French ministries and governmental agencies; (2) data provided by the Lyon local authorities on the step by step evolution of the LEZ implementation; (3) data provided by shippers and logistics service providers on the logistical implications of LEZ in terms of local traffic and product supply towards stores, pick-up points and consumers' homes; and (4) consultation of various Facebook accounts created by citizens to discuss pollution issues in Lyon. The data collected allows a first diagnosis of the influence of LEZ on the monitoring of supply chains in the Lyon area, notably in the context of convenience goods.

\subsection{The LEZ of the Lyon Metropolitan Area}

Lyon is a particularly important city from an economic point of view, the only French metropolis assuming almost all the possible territorial skills over its entire territory (Dumont, 2013). With more than a million and a half inhabitants, it is the second largest urban area in France after Paris and before Marseille. Geographically, the city is located at the confluence of two rivers, the Saône and the Rhône, and dominates the Rhône valley, which extends between the Alps in the east and the Massif Central in the west. From a logistical point of view, the Rhône trench is a major traffic route since the famous A7 motorway and the Paris-Marseille rail link are located there. All this leads to Lyon becoming a real "hub" between the Paris Basin in the North and the shores of the Mediterranean in the South. In other words, Lyon is an interface metropolis between Northern and Southern Europe (Fricke, 2020). While the Lyon metropolitan area is a very sensitive territory to air pollution, the reasons are to be found in this dual geographical and logistical dimension, to which are added very strong human activities and a significant industrial cluster. Thus, in 2016, on a typical day, the average PM10 particle concentration ranged from $10 \mu \mathrm{g} / \mathrm{m}^{3}$ (at the quietest hours of the night) to $45 \mu \mathrm{g} / \mathrm{m}^{3}$ in the late morning due to pollutant emissions generated by transportation.

As underlined, air pollution has disastrous effects, both in terms of public health (Kampa \& Castanas, 2008) and in terms of damaging a city's image in the media. This is even more true for the Lyon metropolitan area, which has been seeking to renew its image thoroughly for the past three decades by developing territorial marketing 
strategies, particularly with the implementation of ambitious urban and architectural projects (Adam \& Laffont, 2018). The question of "green mobility" in line with territorial marketing strategies is therefore important, and has given rise to many experiments, of which one of the best known is the Optimod' Lyon project (Colfedy, 2016). It is therefore natural that the local authorities of the Lyon metropolitan area have decided to set up a LEZ as from January 2020, following other successful European experiences. The decision, of a political nature, was taken under pressure from multiple stakeholders (inhabitants, associations, etc.), particularly since Lyon is a recurrent victim of ozone peaks resulting from the spread of primary pollutants such as NOx and volatile organic compounds. Even if the situation has improved slightly according to ATMO Auvergne-Rhône-Alpes, it is sufficiently worrying to lead to the adoption of drastic regulations that are directly inspired by the implementation of other LEZs in Europe.

The restrictions adopted concern the circulation of vehicles and their parking. Within LEZ, access for light commercial vehicles and heavy trucks is limited only to those that comply with strict conditions regarding greenhouse gas emissions, effectively prohibiting the circulation of older vehicles and obliging companies to invest in a renewed fleet. Here we find the fundamentals of sustainable city logistics, as described above, and the impact of regulations on strategic corporate behavior, as described in the SCP paradigm. However, the local authorities have taken care to support the companies in the necessary transformation of their practices. Thus, in addition to existing national aid, Lyon metropolitan area provides ad hoc aid to facilitate the purchase of green vehicles ( $100 \% \mathrm{NGV}, 100 \%$ electric or $100 \%$ hydrogen). Table 2 shows the amount of aid according to the type of motorization. In total, a budget of $€ 1$ million over three years will be allocated by local authorities to support craftsmen and SMEs to enable them to buy or lease green vehicles.

Table 2. Amount of flat-rate aid provided in 2020 by Lyon metropolitan area by vehicle category and energy used (in euros, for each vehicle)

\begin{tabular}{llll}
\hline & $\mathbf{1 0 0 \%} \mathbf{~ N G V}$ & $\mathbf{1 0 0 \%}$ electric & $\mathbf{1 0 0 \%}$ hydrogen \\
\hline Heavy truck & 10000 & 10000 & 13000 \\
Light commercial vehicle & 5000 & 5000 & 8000 \\
Electrically assisted delivery tricycle & - & 300 & - \\
\hline
\end{tabular}

Source: The authors.

The interest of the implementation of the Lyon's LEZ is to highlight the intensity of interactions between stakeholders in order to bring out compromise solutions. For several years now, residents have been involved in discussions on policies to reduce air pollution in the Lyon metropolitan area. Neighborhood committees have thus set up "air quality" commissions since 2013, the objective of which is to call on local authorities to address the issue of residents' exposure to air pollution (Roussel et al., 2018). More broadly, following consultation with the various economic actors in the territory, but also following the observations made during the regulatory consultation on the LEZ project, the local authorities took care to adapt the framework previously defined by the local context, in particular by granting exemptions to traffic and parking restrictions. The main derogations, of three types, are listed in Table 3. The flexibility of the system extends to the granting of individual derogations on a case-by-case basis for companies meeting specific eligibility criteria. Requests and the duration of derogations are then examined by the local authorities taking into account a specific context and situation.

Table 3. Types of derogations from traffic and parking restrictions in the LEZ of the Lyon metropolitan area

\begin{tabular}{|c|c|c|}
\hline $\begin{array}{l}\text { Vehicles benefiting from a permanent } \\
\text { derogation }\end{array}$ & $\begin{array}{l}\text { Vehicles benefiting from a derogation } \\
\text { for a period of three years }\end{array}$ & $\begin{array}{l}\text { Temporary derogation studied } \\
\text { individually }\end{array}$ \\
\hline $\begin{array}{ll}\text { - } & \text { Priority general interest vehicles } \\
\text { - } & \text { Ministry of Defense vehicles } \\
\text { - } & \text { Vehicles used by people with } \\
\text { disabilities } \\
\text { - } & \text { Specialized self-propelled vehicles } \\
\text { - } & \text { Civil security vehicles } \\
\text { - } & \text { Exceptional convoy vehicles }\end{array}$ & $\begin{array}{ll}\text { - } & \text { Refrigerated vehicles } \\
\text { - } & \text { Concrete mixers } \\
\text { - } & \text { Trucks and dump trucks } \\
\text { - } & \text { Trucks and machine carriers } \\
\text { - } & \text { Trucks and water tankers }\end{array}$ & $\begin{array}{l}\text { - Vehicles used for an exceptional } \\
\text { event or TV/cinema shooting } \\
\text { - Vehicles used by companies in a } \\
\text { state of suspension of payment } \\
\text { - Vehicles assigned to a public service } \\
\text { (one-off interventions) } \\
\text { - } \quad \text { Market supply vehicles }\end{array}$ \\
\hline
\end{tabular}

Source: The authors.

The example of the LEZ in Lyon is particularly interesting because it indicates that the success of the approach is 
based, thanks to strategic interactions between stakeholders, on the ability to allow consensual solutions to emerge gradually. As the President of the Lyon metropolitan area noted in January 2019, "we must all commit ourselves, local authorities, companies, associations, and citizens, in order to act each for a sustainable territory that can be passed on to future generations. The economic development of the metropolis is compatible with an ecological awareness that is becoming necessary. It is a dual challenge in terms of public health and the attractiveness of our region" (Press Release). Upstream, as was the case with the LEZ of the Lyon metropolitan area in 2019, communication campaigns initiated by local authorities are necessary to inform and raise awareness of the approach and to convert companies to this new (environmental) regulatory system; in their absence, the acceptability of the transport policies is threatened, as shown by Soria-Lara et al. (2019). Finally, local support measures, in addition to national tax incentives, will undoubtedly facilitate the deployment of LEZs by permanently changing the strategic behavior of companies.

Here again, the case of Lyon metropolitan area highlights the importance of a proactive (and financially transparent) strategy to support the changes required by the energy transition. It is at this price that LEZs will not be considered by private decision-makers as a new variation of punitive ecology, but as a natural evolution towards sustainable city logistics. In other words, the case of Lyon is not isolated. On the contrary, it corresponds to the beginnings of a profound evolution of city logistics in the coming years. In September 2020, the French government published a decree that makes it compulsory to implement LEZs in the most polluted areas. With this new decree, seven new zones will have to be set up by 2021 by French metropolises: Aix-Marseille, Nice, Toulon, Toulouse, Montpellier, Strasbourg and Rouen. The most problematic case remains that of Marseille (Plummer, 2018), one of the most polluted cities in France, and which is known for a totally anarchic circulation of delivery vehicles.

\subsection{Comparative Analysis with Barcelona (Spain)}

If Lyon is an interesting case, its possible specificity in terms of the establishment of a LEZ still needs to be analyzed. From this point of view, a comparison with an equivalent European city appears relevant. The case of Barcelona meets this condition, especially since the city has been involved for a long time in a sustainable city logistics strategy, as highlighted above. Moreover, Barcelona is the second largest city in Spain (1.6 million inhabitants), just as Lyon is the second largest city in France, and in both cases the metropolitan area - as logistical node - is crossed by large and continuous flows of products. As a direct consequence, since 2002 Barcelona has exceeded the WHO PM10 particle concentration level and the European Union carbon dioxide level (Moreno-Jimenez et al., 2016). Between 2010 and 2017, air pollution would have caused an average of 425 premature deaths per year in the capital of Catalonia. Figure 3 shows the dramatic level of air pollution for the city center.

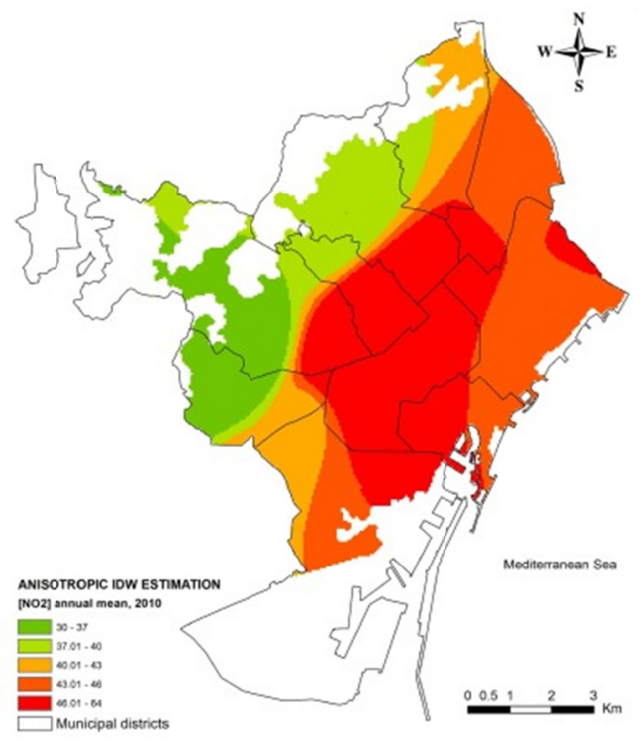

Figure 3. Air pollution in Barcelona

Source: Moreno-Jimenez et al., 2016.

This is why Barcelona's local authorities decided to set up a LEZ to restrict the access of the most polluting cars to 
the city center (in 2020), before extending the measure to delivery vehicles (in 2021). Monitored by 150 cameras, Barcelona's LEZ covers $95 \mathrm{~km}^{2}$, twenty times the size of Madrid's LEZ, and includes four satellite cities in addition to the urban area itself. The goal is to reduce air pollution by $20 \%$ in four years, with 125000 fewer vehicles. If this is not achieved within three years, Barcelona could introduce a congestion charge on the London model, taxing all vehicles entering the city. Already, diesel vehicles registered before 2006 and gasoline vehicles registered before 2000 are no longer allowed to travel, with some exceptions, Monday to Friday from 7 a.m. to 8 p.m. throughout the city. As in the case of Lyon, the heavy trucks and light commercial vehicles that will circulate in the Bracelona's LEZ will be $100 \%$ NGV, $100 \%$ electric or $100 \%$ hydrogen by 2030 .

However, in comparison with Lyon, the penalty system used in Barcelona is extremely rigorous and dissuasive. Indeed, all vehicles must be authorized to circulate in the city, and failure to have the necessary authorization immediately leads to a fine. The least severe fines range from 100 to 499 euros, while the most serious fines range from 500 to 1800 euros. In the event of a repeat offence, the driver may receive a fine increased by $30 \%$, and the police will give the driver 90 minutes to leave the LEZ before applying another fine. Thanks to this particularly coercive policy, the local authorities hope for a rapid decrease in nitrogen dioxide emissions of $15 \%$. It can therefore be concluded that Lyon and Barcelona are similar in terms of the technical organization of the LEZ, with comparable choices for limited access to urban space. On the other hand, the local authorities in Lyon favor communication and persuasion to make people accept the rules, while the local authorities in Barcelona favor punishment in case of non-compliance with the rules. This is undoubtedly a cultural difference in the governance of LEZs that future work can explore in depth.

\section{Conclusion}

As a major societal issue that goes far beyond the borders of logistics, the energy transition is now in the media and represents a major challenge for a growing number of companies. The essential characteristic of sustainable city logistics is to focus on an economic activity, the delivery of products in the city, which is part of both the private space (practices and strategies of companies) and the public space (professional transport on a road shared with citizens). This ambivalence certainly exists for many other logistical activities, but it is exacerbated here because the city is a geographically confined and increasingly congested space. The energy transition is changing the cards and leading local authorities to implement a system of coercive constraints from which companies can no longer escape (Atkinson, 2013). There is no doubt that not all the implications of the current developments, particularly with regard to LEZ, have been studied and evaluated, which undoubtedly merits sustained attention in the coming years in order to understand the dynamics of the energy transition better.

The challenges related to the energy transition will translate into an in-depth reflection for companies: (1) on how best to organize transport (taking into account its known environmental effects); and (2) on drastically reducing waste, with an optimization of the use of existing energies, as a first step, and on a search for economically viable alternative energy sources, as a second step (Inkinen \& Hämäläinen, 2020). While the optimized logistics perspectives deployed today shine a new light, through their contribution to the energy transition, they are based on an old idea, and disseminated in the academic literature: the search for logistics efficiency through a drastic reduction in waste and redundancies in the management of physical flows. The activities related to city logistics thus raise as many environmental issues and the complex set of constraints linked to them challenges decision-makers, particularly in the management of supply chains, to move towards a more liveable city.

On a conceptual level, the mobilization of the SCP paradigm is, in our opinion, a fruitful way to understand the dynamics of supply chains better. While political interventionism has been constant, particularly in France, since the 1970s in the retailing industry (Filser et al., 2020), the application of the SCP paradigm offers a stimulating framework that can renew the economic, behaviorist and strategic approaches widely used in the past. This is particularly true with regard to city logistics, to address the problems of allocating resources on new environmental models, which raise the question of the distribution of gains and costs related to the delivery of products in the city. City logistics clearly shows that stakeholders in the public and private spheres are, willingly or unwillingly, in close interaction. This requires rethinking political decisions as constraints for the implementation of appropriate strategic behavior, but also as levers for more efficient action. The research avenues open to researchers in logistics management seem sufficiently solid to justify the formalization of original programs in this direction.

\section{Acknowledgments}

The authors thank two anonymous reviewers of the Journal of Management \& Sustainability for their insightful comments which helped to greatly improve the final version of the paper. 


\section{References}

Adam, M., \& Laffont, G.-H. (2018). Conjuguer singularité et conformité pour se positionner sur le marché international de l'urbain: Confluence et le renouvellement de l'image de Lyon. Confins: Revue Franco-Brésilienne de Géographie, 36, 1-17. https://doi.org/10.4000/confins.14614

Akyol, D., \& De Koster, R. (2018). Determining time windows in urban freight transport: A city cooperative approach. Transportation Research Part E: Logistics \& Transportation Review, 118, 34-50. https://doi.org/10.1016/j.tre.2018.07.004

Andrés, L., \& Padilla, E. (2018). Driving factors of GHG emissions in the EU transport activity. Transport Policy, 61, 60-74. https://doi.org/10.1016/j.tranpol.2017.10.008

Andriosopoulos, K., \& Silvestre, S. (2017). French energy policy: A gradual transition. Energy Policy, 106, 376-381. https://doi.org/10.1016/j.enpol.2017.04.015

Atkinson, H. (2013). English local authorities and the fight against climate change. Journal of Management \& Sustainability, 3(3), 46-54. https://doi.org/10.5539/jms.v3n3p46

Bain, J. (1959/1987). Industrial organization: A treatise. Stamford (CT), JAI Press.

Borsenberger, C. (2018). Consolidation in urban logistics: What could we learn from past experiences and economy theory? In P. Parcu, T. Brennan \& V. Glass (Eds.), New business and regulatory strategies in the postal sector (pp. 79-89). Cham, Springer. https://doi.org/10.1007/978-3-030-02937-1_7

Busch, H., \& Anderberg, S. (2015). Green attraction Transnational municipal climate networks and green city branding. Journal of Management \& Sustainability, 5(4), 2-16. https://doi.org/10.5539/jms.v5n4p1

Chamberlin, E. (1933). The theory of monopolistic competition: A re-orientation of the theory of value. Cambridge (MA). Harvard University Press.

Colfedy, J. (2016). Optimod' Lyon ou la mise en synergie des acteurs publics et privés pour une gestion optimale de l'intermodalité. Pollution Atmosphérique, 231-232, 217-231. Retrieved from https://lodel.irevues.inist.fr/pollution-atmospherique/index.php?id=5893

Cyrys, J., Peters, A., Soentgen, J., \& Wichmann, H. (2014). Low emission zones reduce PM10 mass concentrations and diesel soot in German cities. Journal of the Air \& Waste Management Association, 64(4), 481-487. https://doi.org/10.1080/10962247.2013.868380

da Silva Batalhao, A., Teixeira, D., de Fatima Martins, M., van Bellen, H.-S., \& Ferreira Caldana, A.-C. (2019). Sustainability indicators: Relevance, public policy support and challenges. Journal of Management \& Sustainability, 9(2), 173-190. https://doi.org/10.5539/jms.v9n2p173

da Silva Batalhao, A., Teixeira, D., Lobo de Godoi, E., \& Prates, G. (2018). Exploring the local sustainability approach using indicators. Journal of Management \& Sustainability, 8(4), 39-53. https://doi.org/10.5539/jms.v8n4p39

Dablanc, L., Savy, M., Veltz, P., Culoz, A., \& Vincent, M. (2017). Des marchandises dans la ville: Un enjeu social, environnemental et économique majeur. Paris, Terra Nova.

de la Esperanza Mata Pérez, M., Scholten, D., \& Smith Stegen, K. (2019). The multi-speed energy transition in Europe: opportunities and challenges for EU energy security. Energy Strategy Reviews, 26, Article 100415. https://doi.org/10.1016/j.esr.2019.100415

Dumont, G.-F. (2013). Lyon: La revanche d'une métropole? Population \& Avenir, 712, 3. https://doi.org/10.3917/popav.712.0003

Ellison, R., Greaves, S., \& Hensher, D. (2013). Five years of London's low emission zone: Effects on vehicle fleet composition and air quality. Transportation Research Part D: Transport \& Environment, 23, 25-33. https://doi.org/10.1016/j.trd.2013.03.010

Filser, M., des Garets, V., \& Paché, G. (2020). La distribution: Organisation et stratégie (3rd ed.). Caen, Editions Management \& Société.

Fricke, C. (2020). European dimension of metropolitan policies: Policy learning and reframing of metropolitan regions. Cham, Springer. https://doi.org/10.1007/978-3-030-14614-6

Gauthier, C., \& Lowitzsch, J. (2019). Outlook. Energy transition and regulatory framework 2.0: insights from the European Union. In J. Lowitzsch (Ed.), Energy transition: Financing consumer co-ownership in renewables (pp. 733-765). Cham, Palgrave Macmillan. https://doi.org/10.1007/978-3-319-93518-8_30 
Grillo, F., \& Laperrouze, J. (2013). Measuring the cost of congestion on urban area and the flexible congestion rights. Journal of Management \& Sustainability, 3(2), 40-55. https://doi.org/10.5539/jms.v3n2p40

Host, S., Honoré, C., Joly, F., Saunal, A., Le Tertre, A., \& Medina, S. (2020). Implementation of various hypothetical low emission zone scenarios in Greater Paris: assessment of fine-scale reduction in exposure and expected health benefits. Environmental Research, 185, Article 109405. https://doi.org/10.1016/j.envres.2020.109405

Hulkkonen, M., Mielonen, T., \& Prisle, N. (2020). The atmospheric impacts of initiatives advancing shifts towards low-emission mobility: A scoping review. Science of the Total Environment, 713, Article 136133. https://doi.org/10.1016/j.scitotenv.2019.136133

Inkinen, T., \& Hämäläinen, E. (2020). Reviewing truck logistics: Solutions for achieving low emission road freight transport. Sustainability, 12, Article 6714. https://doi.org/10.3390/su12176714

Jiang, W., Boltze, M., Groer, S., \& Scheuvens, D. (2017). Impacts of low emission zones in Germany on air pollution levels. Transportation Research Procedia, 25, 3370-3382. https://doi.org/10.1016/j.trpro.2017.05.217

Kampa, M., \& Castanas, E. (2008). Human health effects of air pollution. Environmental Pollution, 151(2), 362-367. https://doi.org/10.1016/j.envpol.2007.06.012

Koblianska, I. (2018). Ecologically related transformation of the logistics theory: Directions and content. Environmental Economics, 9(4), 44-49. https://doi.org/10.21511/ee.09(4).2018.04

Ku, D., Bencekria, M., Kim, J., Lee, S., \& Lee, S. (2020). Review of European low emission zone policy. Chemical Engineering, 78, 241-246. https://doi.org/10.3303/CET2078041

Lagorio, A., Pinto, R., \& Golini, R. (2016). Research in urban logistics: A systematic literature review. International Journal of Physical Distribution \& Logistics Management, 46(10), 908-931. https://doi.org/10.1108/IJPDLM-01-2016-0008

Levy, M., Weitz, B., \& Grewal, D. (2018). Retailing management (10th ed.). New York (NY), McGraw-Hill.

Lopez, O. (2018). Urban vehicle access regulations. In V. Zeimpekis, E. Aktas, M. Bourlakis \& I. Minis (Eds.), Sustainable freight transport: Theory, models, and case studies (pp. 139-163). Cham, Springer.

Martayan, E., Laurent, J., \& Blond, O. (2020). L'acceptation sociale des zones à faibles émissions. Paris, Global Urban Air Pollution Observatory.

Mason, E. (1939). Price and production policies of large-scale enterprise. American Economic Review, 29(1), 61-74. Retrieved from https://www.jstor.org/stable/i331339

Montoya-Torres, J., Muñoz-Villamizar, A., \& Vega-Mejía, C. (2016). On the impact of collaborative strategies for goods delivery in city logistics. Production Planning \& Control, 27(6), 443-455. https://doi.org/10.1080/09537287.2016.1147092

Morana, J., Gonzalez-Feliu, J., \& Semet, F. (2014). Urban consolidation and logistics pooling. In J. Gonzalez-Feliu, F. Semet \& J.-L. Routhier (Eds.), Sustainable urban logistics: Concepts, methods and information systems (pp. 187-210). Heidelberg, Springer. https://doi.org/10.1007/978-3-642-31788-0_10

Moreno-Jimenez, A., Cañada-Torrecilla, R., Vidal-Domínguez, M.-J., Palacios-Garcia, A., \& Martinez-Suarez, P. (2016). Assessing environmental justice through potential exposure to air pollution: A socio-spatial analysis in Madrid and Barcelona, Spain. Geoforum, 69, 117-131. https://doi.org/10.1016/j.geoforum.2015.12.008

Nuzzolo, A., Comi, A., Ibeas, A., \& Moura, J. (2016). Urban freight transport and city logistics policies: Indications from Rome, Barcelona, and Santander. International Journal of Sustainable Transportation, 10(6), 552-566. https://doi.org/10.1080/15568318.2015.1014778

Olaitan, O.-S. (2019). Planning: The town planners' perspective. Journal of Geography \& Regional Planning, 12(4), 52-59. https://doi.org/10.5897/JGRP2016.0616

Patier, D., \& Routhier, J.-L. (2020). Urban logistics in the light of sustainable development: Still a long way to go. Transportation Research Procedia, 46, 93-100. https://doi.org/10.1016/j.trpro.2020.03.168

Plummer, W. (2018). Les grandes villes françaises face au fléau des embouteillages. Le Figaro, March 14. Retrieved from https://www.lefigaro.fr/

Porter, M. (1980). Competitive strategy: Techniques for analyzing industries and competitors. New York (NY), The Free Press. 
Pouponneau, M., Forestier, B., \& Cape, F. (2019). Les zones à faibles émissions (low emission zones) à travers l'Europe: déploiement, retours d'expériences, évaluation d'impacts et efficacité du système. Paris, ADEME.

Pulawska, S., \& Starowicz, W. (2014). Ecological urban logistics in the historical centers of cities. Procedia-Social \& Behavioral Sciences, 151, 282-294. https://doi.org/10.1016/j.sbspro.2014.10.026

Richey Jr., R., Roath, A., Whipple, J., \& Fawcett, S. (2010). Exploring a governance theory of supply chain management: Barriers and facilitators to integration. Journal of Business Logistics, 31(1), 237-256. https://doi.org/10.1002/j.2158-1592.2010.tb00137.x

Robinson, J. (1933/1969). The economics of imperfect competition (2nd ed.). New York (NY), St. Martin's Press.

Roussel, I., Rocher, L., \& Aschan-Leygonie, C. (2018). Air, climat, énergie: Convergences et contradictions à l'échelle urbaine. L'exemple lyonnais. Pollution Atmosphérique, 237-238, 1-12. https://doi.org/10.4267/pollution-atmospherique.6723

Santos, F., Gómez-Losada, A., \& Pires, J. (2019). Impact of the implementation of Lisbon low emission zone on air quality. Journal of Hazardous Materials, 365, 632-641. https://doi.org/10.1016/j.jhazmat.2018.11.061

Savelsbergh, M., \& Van Woensel, T. (2016). City logistics: challenges and opportunities. Transportation Science, 50(2), 579-590. https://doi.org/10.1287/trsc.2016.0675

Scherer, F., \& Ross, D. (1990). Industrial market structure and economic performance (3rd ed.). Boston (MA), Houghton Mifflin.

Schmitt, P., \& Van Well, L. (Eds.) (2015). Territorial governance across Europe: Pathways, practices and prospects. London, Routledge. https://doi.org/10.4324/9781315716220

Sedaghatnia, S., Lamit, H., Ghahramanpouri, A., \& Bt Mohamad, S. (2013). An evaluation of residents' quality of life through neighborhood satisfaction in Malaysia. Environmental Management \& Sustainable Development, 2(1), 114-125. https://doi.org/10.5296/emsd.v2i1.3254

Soria-Lara, J., Tarriño-Ortiz, J., Bueno, P., Ortega, A., \& Vassallo, J. (2019). A collaborative appraisal framework to evaluate transport policies for improving air quality in city centres. Cities, 92, 112-124. https://doi.org/10.1016/j.cities.2019.03.017

Thieffry, P. (2016). Environmental protection and European Union energy policy: Energy transition after the Paris agreement. ERA Forum, 17(4), 449-465. https://doi.org/10.1007/s12027-017-0453-8

Tirole, J. (1988). The theory of industrial organization. Cambridge (MA), The MIT Press.

Tögel, M., \& Spicka, L. (2014). Low-emission zones in European countries. Transactions on Transport Sciences, 7(3), 97-108. https://doi.org/10.2478/trans-2014-0007

Uzunidis, D. (2016). Propaedeutics in the theory of the industrial organisation: The SCP (structure, conduct, performance) model. Journal of Innovation Economics \& Management, 20, 197-215. https://doi.org/10.3917/jie.020.0197

Wolff, H. (2014). Keep your clunker in the suburb: low - emission zones and adoption of green vehicles. Economic Journal, 124(578), F481-F512. https://doi.org/10.1111/ecoj.12091

\section{Copyrights}

Copyright for this article is retained by the author, with first publication rights granted to the journal.

This is an open-access article distributed under the terms and conditions of the Creative Commons Attribution license (http://creativecommons.org/licenses/by/4.0/). 